\title{
Herd management and social variables associated with bulk tank somatic cell count in dairy herds in the eastern United States
}

\author{
R. L. Schewe, ${ }^{* 1}$ J. Kayitsinga,† G. A. Contreras, $\ddagger$ C. Odom,§ W. A. Coats,§ P. Durst,\# E. P. Hovingh,II

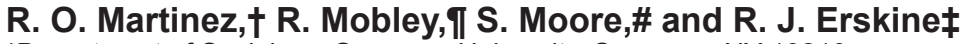 \\ *Department of Sociology, Syracuse University, Syracuse, NY 13210 \\ †Julian Samora Research Institute, and \\ ‡Department of Large Animal Clinical Sciences, Michigan State University, East Lansing 48824 \\ $\S$ Social Science Research Center, College of Arts and Sciences, Mississippi State University, Mississippi State 39762 \\ \#Michigan State University Extension, Michigan State University, East Lansing 48824 \\ IIDepartment of Veterinary and Biomedical Sciences, The Pennsylvania State University, University Park 16802 \\ ๆCollege of Agriculture and Food Sciences, Florida Agricultural and Mechanical University, Tallahassee 32307
}

\section{ABSTRACT}

The ability to reduce somatic cell counts (SCC) and improve milk quality depends on the effective and consistent application of established mastitis control practices. The US dairy industry continues to rely more on nonfamily labor to perform critical tasks to maintain milk quality. Thus, it is important to understand dairy producer attitudes and beliefs relative to management practices, as well as employee performance, to advance milk quality within the changing structure of the dairy industry. To assess the adoption rate of mastitis control practices in United States dairy herds, as well as assess social variables, including attitudes toward employees relative to mastitis control, a survey was sent to 1,700 dairy farms in Michigan, Pennsylvania, and Florida in January and February of 2013. The survey included questions related to 7 major areas: sociodemographics and farm characteristics, milking proficiency, milking systems, cow environment, infected cow monitoring and treatment, farm labor, and attitudes toward mastitis and related antimicrobial use. The overall response rate was $41 \%$ (21\% in Florida, 39\% in Michigan, and $45 \%$ in Pennsylvania). Herd size ranged from 9 to 5,800 cows. Self-reported 3-mo geometric mean bulk tank SCC (BTSCC) for all states was 194,000 cells/mL. Multivariate analysis determined that proven mastitis control practices such as the use of internal teat sealants and blanket dry cow therapy, and not using water during udder preparation before milking, were associated with lower BTSCC. Additionally, farmer and manager beliefs and attitudes, including the perception of mastitis problems and the threshold of concern if BTSCC is above 300,000 cells $/ \mathrm{mL}$, were associated with BTSCC.

Received September 10, 2014.

Accepted July 9, 2015.

${ }^{1}$ Corresponding author: rlschewe@syr.edu
Ensuring strict compliance with milking protocols, giving employees a financial or other penalty if BTSCC increased, and a perceived importance of reducing labor costs were negatively associated with BTSCC in farms with nonfamily employees. These findings highlight the need for a comprehensive approach to managing mastitis, one that includes the human dimensions of management to maintain the practice of scientifically validated mastitis control practices.

Key words: mastitis, behavior, attitudes, employees

\section{INTRODUCTION}

Mastitis continues to result in major economic losses to the US dairy industry, decreases farm productivity, and reduces the quality of dairy foods (Ma et al., 2000; Losinger, 2005; Cha et al., 2011; Hogeveen and Lam, 2011). The ability to reduce mastitis depends on effective and consistent application of established mastitis control practices. For example, farms that consistently use postmilking teat disinfection (PMTD), blanket dry cow therapy (BDCT), coliform mastitis vaccines, or provide inorganic bedding maintain lower bulk tank somatic cell counts (BTSCC) or clinical mastitis incidence than noncompliant herds (Erskine et al., 1987; Wenz et al., 2007; Hogan and Smith, 2012). However, some dairy herds continue to struggle with compliance of these proven mastitis control practices.

Over the past 2 decades, a marked shift has occurred in herd size of dairy farms in the United States. Farms with fewer than 100 cows accounted for $49 \%$ of the country's milk cows in 1992, but just $17 \%$ of milk cows in 2012. In contrast, farms with at least 1,000 cows accounted for $49 \%$ of all milk cows in 2012, up from $10 \%$ in 1992 (MacDonald and Newton, 2014). As variability in herd size increases, dairy farms are also becoming increasingly varied in terms of employment practices and organization (Jackson-Smith and Barham, 2000). Thus, 
the diversity in farm size and labor structure makes it difficult to design and apply standardized mastitis control programs across US dairy farms.

Despite progress in mastitis control programs and their positive effect on udder health, their effectiveness and consistent application depend on dairy personnel (Fuhrmann, 2002; Brasier et al., 2006; Stup et al., 2006). Research has also demonstrated the importance of farmer attitudes and values in determining mastitis rates and antimicrobial use (Vaarst et al., 2002; Sato et al., 2008). In a survey of 336 Dutch dairy farms (Jansen et al., 2009), farmers' attitudes toward mastitis (e.g., believing mastitis was due to bad luck) were significantly associated with increased BTSCC and incidence of clinical mastitis as much as self-reported control procedures (e.g., forestripping cows before milking, or checking the milking vacuum daily). Therefore, to facilitate the development of mastitis control programs that successfully improve milk quality and reduce antimicrobial use, it is necessary to evaluate both farm practices and social factors including knowledge, behaviors, and beliefs about mastitis control and antimicrobial use, as well as labor management practices and attitudes.

Based on previous studies, it is hypothesized that farmers' and managers' attitudes, values, and employee management will have at least as large an effect on BTSCC as conventional herd and mastitis management practices. The purpose of this study was to determine the relative and combined effects of herd management and social variables, especially those related to farm labor, on self-reported BTSCC across a broad scope of herd sizes and characteristics.

\section{MATERIALS AND METHODS}

\section{Dairy Farm Selection}

Data for this study were collected using a mail survey that was sent to a stratified random sample of USDA grade A certified dairy farms in Michigan (MI), Pennsylvania (PA), and Florida (FL). Addresses of 7,983 grade A certified dairy farms in FL, MI, and PA were obtained to serve as the total farm population from which to select our survey sample.

Prior to sample selection, dairy farms in both MI and PA were stratified by herd size due to the small number of large herds in those states. Additionally, stratification was necessary to ensure that the diversity in labor structure across small and large dairies was accounted for. Therefore, MI and PA farms were stratified into large or small-to-medium strata based on herd size distribution in each state. In PA, large farms were defined as those $>250$ cows, and in MI, large farms were defined as those $>500$ cows due to the larger mean and median herd size as compared with PA. Due to the small number of dairy farms in FL, all 128 grade A farms in this state were included in the sample. This stratified sampling requires all analysis to be properly weighted to account for differential probability of selection across strata; sample weighting procedures are described in the statistical analysis section.

In MI, the sampling frame was obtained through Freedom of Information Act (FOIA) requests to the MI Department of Agriculture and Rural Development (MDARD), the MI Department of Environmental Quality (MDEQ), and consultation with MI State University Extension. The MDARD provided a spreadsheet of the names and addresses of all current grade A dairy farms in the state. Although herd size was also requested, the MDARD declined this portion of our FOIA request citing privacy concerns. This was a problem because without herd size, stratification would not be possible. However, a FOIA request to the MDEQ provided a spreadsheet of the current and pending concentrated animal feeding operation (CAFO) permits in the state. The CAFO records included name, address, and type of animal operation (i.e., dairy), and identified those dairy farms with $>700$ cows (the MDEQ requirement for a permit). This identified 98 farms with $>700$ cows to be included in the large-farm stratum. The updated sampling frame was then reviewed by MI State University Dairy Extension personnel (including campus faculty and extension educators) to identify any additional farms known to have over 500 cows. This added an additional 8 farms to the large-farm stratum. This resulted in a final sampling frame for MI of 106 large farms (i.e., $>500$ cows) and 1,651 small ( $\leq 250$ cows) to medium farms (250-500 cows). To ensure adequate representation of large farms, all 106 farms in the large-farm stratum were sampled, giving them a sampling ratio of 1 . Using a random number generator, 646 farms from the small-to-medium farm stratum were sampled, giving them a sampling rate of 0.39 and a sampling probability weight of 2.56 (pweight $=1$ / sampling ratio). The sample size of 646 farms in the small-to-medium farm stratum was designed to provide a $5 \%$ confidence interval for a response rate of approximately 40\% (Kenny, 1987).

In PA, co-investigator E. Hovingh obtained the sampling frame through the PA Department of Agriculture, which provided access to a confidential list of grade A certified farms including herd size. Adhering to a privacy agreement with the PA Department of Agriculture, unique numerical identifiers were assigned to each farm, which produced a spreadsheet including only anonymous identifiers and herd size to be used by survey administrators to define strata and samples. A FOIA request to the PA Department of Environmental 
Protection provided a spreadsheet of all current and pending CAFO permits including farm name, address, type of animal operation (i.e., dairy), and animal units. Comparing the initial sampling frame to the CAFO records, the sampling frame was verified and corrected by comparing the reported number of cows to the CAFO list. The final sampling frame included 109 large farms ( $>250$ cows) and 5,989 farms in the small-to-medium farm stratum. To ensure adequate representation of large farms, all 109 farms in the large-farm stratum were sampled, giving them a sampling ratio of 1 . Using a random number generator, 711 farms from the smallto-medium farm stratum were sampled, giving them a sampling rate of 0.12 and a pweight of 8.42. As in MI, the sample size of 711 farms in the small-to-medium farm stratum was designed to provide a $5 \%$ confidence interval if for a response rate of approximately $40 \%$. Co-investigator R. Mobley obtained the sampling frame for FL that included all currently certified grade A farms, names, and addresses.

\section{Survey Questionnaire}

Design and Content. The mailed survey totaled 20 pages and an additional lined page for written comments (full text of the survey available at http:/ qualitymilkalliance.com/wp-content/uploads/2015/01/133813108-

A-Survey-of-Mastitis-on-Dairy-Farms.pdf).

Survey questions were based upon existing scientific literature concerning the practices and attitudes associated with BTSCC, mastitis, or both. Questions covered 7 categories: (1) sociodemographics and farm characteristics (age, education, race, Mennonite or Amish, native English speaking, herd size, and so on; Norman et al., 2011); (2) milking proficiency (pre- and postmilking teat disinfection, wearing gloves during milking, and so on; Erskine et al., 1987; Wenz et al., 2007); (3) milking systems (parlor type, maintenance patterns, and so on; Mein, 2012); (4) cow environment (housing, grouping, bedding, and so on; Dufour et al., 2011); (5) infected cow monitoring and treatment (record keeping, use of cultures, and so on; Wenz et al., 2007; Bhutto et al., 2011); (6) farm labor (number of workers, employee management strategies, and so on; Fuhrmann, 2002; Brasier et al., 2006; Stup et al., 2006); and (7) attitudes toward mastitis and related antimicrobial agent use (farm goals, belief in causes of mastitis, sources of information about mastitis and antimicrobials, and so on, Vaarst et al., 2002; Wenz et al., 2007; Sato et al., 2008; Jansen et al., 2009).

To ensure measurement quality and internal consistency, Likert scales or yes or no questions were used whenever possible. The survey was pretested by project team investigators and extension agents from all 3 states and then face-to-face pretests were conducted with dairy producers in MI to refine questions. Pretests indicated that average time to completion was approximately $15 \mathrm{~min}$ and helped further clarify questions. Balancing desire for depth of data with the priority to increase response rate, 71 questions were retained in the final survey.

Farm Contact. Survey administration followed strategies recommended by Dillman et al. (2009) to maximize response rate, including first-class postage, full-color covers, personalized addresses, a distinctively sized envelope with color picture, 5 points of contact, and a $\$ 2$ bill. The first mailing was sent on January 17, 2013, and included a cover letter, survey, and $\$ 2$ incentive. The second mailing was sent on February 1, 2013, to all nonrespondents and included a full-color personalized reminder postcard. The third mailing was sent on February 8, 2013, to all nonrespondents and included a second copy of the cover letter and survey. The fourth mailing was sent on February 15, 2013, to all nonrespondents and included a second copy of the reminder postcard. The fifth and final mailing was sent on February 25, 2013, to all nonrespondents and included a third copy of the cover letter and survey.

\section{Statistical Analysis}

Analysis proceeded through 3 stages: (1) factor analysis for dimension reduction among independent variables, (2) bivariate analysis to determine which independent variables to include for multiple regression analysis (included if bivariate $P<0.10$ ), and (3) backward stepwise multivariate regression analysis. All analyses were weighted to account for the sampling design in this study with use of STATA statistical software (StataCorp, 2013). Statistical significance was defined as $P<0.05$.

Sample Representativeness. To ensure that the final sample of respondents was representative, respondents were compared with USDA-reported state averages for production ( $\mathrm{kg}$ per cow per day), herd size, and BTSCC. Independent one-sample $t$-tests were used to compare state averages of respondents (sample) to USDA-reported state averages (population).

Dependent Variable. The dependent variable in this study was the natural log-transformed 3-mo arithmetic mean self-reported BTSCC (LnBTSCC). To determine this variable for each farm, respondents were asked to report their average monthly BTSCC for each of the 3 mo preceding survey completion. If a respondent reported BTSCC for only 1 mo, that month was assigned as the average BTSCC. If a respondent reported BTSCC for only 2 mo, the arithmetic average of those 2 mo was assigned as the average BTSCC. If 
a respondent reported BTSCC for all 3 mo, the arithmetic average of those 3 mo was assigned. This reduced the number of missing cases from $132(21 \%)$ to $28(4 \%)$. These 28 cases were excluded from analysis. The natural log-transformation was used to ensure normality.

Independent Variables. Independent variables were selected for inclusion in the multivariate regression model based upon bivariate associations with LnBTSCC. If bivariate association with LnBTSCC had a $P<0.10$, that independent variable was selected for the multiple regression models. Thus, 33 independent variables were identified (18 binary, 15 continuous or ordinal) to be tested in multiple regression models.

Four of the independent variables retained by bivariate analysis were relevant only to the 289 (weighted $n$ $=1,006,38 \%$ ) farms with nonfamily employees: a scale representing engaged employee management style, a belief that employees play an important role in mastitis problems, the importance of reducing labor costs as a farm goal, and whether employees receive a financial or other penalty if BTSCC increases. Because these variables are relevant only to those farms with employees and were not reported for farms without employees, these 4 variables were excluded from the regression models for the entire sample. They were, however, included in the model run with only the subpopulation of farms with nonfamily employees.

Analytical Weights and Survey Analysis. Because sample strata varied in both size and sampling ratio, it was necessary to appropriately weight the resulting data for analysis to ensure that the data represented the population and did not overrepresent the higher-sampled strata (in this case the large MI and PA farms and all FL farms). Sample weights for the 5 strata were defined as probability weights according to the differential probability of each case being sampled from the population. All analyses were conducted using survey-weighted analysis to account for the effects of stratified sampling on significance levels for parameter estimates. Weighted analysis of complex survey data has been demonstrated to produce unbiased estimates and variances such that inference for a specified significance level can be achieved with correct probability coverage (McDowell and Pitblado, 2002).

Factor Analysis. Factor analysis was performed to reduce the number of independent variables by creating composite measures. Factor analysis was conducted using SPSS statistical software with weights designed to account for the sampling design of this study (IBM Corp., 2012). Six scales were created as composite measures to represent multiple independent variables with one single scale by performing exploratory principal components factor analysis with Varimax rotation (Kim and Mueller, 1978). Scales allow parsimonious analysis and presentation by combining multiple similar variables into a single measure (Kim and Mueller, 1978). To confirm the validity and internal consistency of the scales, both eigenvalues and Cronbach's $\alpha$ were evaluated. Factors with eigenvalues $>1$ and Cronbach's $\alpha>0.6$ were included as independent variables. Once confirmed, all 6 scales were computed as an average score for each component variable to keep the range of responses consistent with those of other independent variables.

Bivariate Analysis. Bivariate associations with LnBTSCC were tested to determine which independent variables to include in multivariate regression $(P<$ 0.10 threshold for inclusion). For binary (dichotomous) variables, means of LnBTSCC were compared between the categories of the independent variables using an adjusted Wald test to test for $P$-value of relationship. For ordinal and continuous variables, Pearson correlations and a 2-tailed significance test for $P$-value with pairwise deletion of missing cases were used.

Multiple Linear Regression. Two ordinary least squares linear regression models were estimated: one for all respondents (model 1) and one for the subpopulation of respondents with nonfamily employees (model 2).

Regression modeling using LnBTSCC as the outcome variable proceeded through 2 stages: (1) full regression models including all independent variables that met the threshold for inclusion in bivariate relationships with LnBTSCC (at $P<0.10$ ), and (2) refined regression models through backward stepwise regression, excluding any variables with $P>0.10$. To test for potential multicollinearity, confounding interactions, or both among independent variables, correlation analysis was performed for all independent variables, and variance inflation factors and tolerance values were analyzed. The correlation matrix indicated only 2 problematic correlations among independent variables: (1) herd location in MI and using sand bedding (Pearson correlation $=0.52, P<0.001)$ and $(2)$ age and years in dairy farming (Pearson correlation $=0.74, P<0.001$ ). A greater proportion of dairies in MI used sand bedding than other states. To address the first correlation, an interaction term for MI and sand bedding was included in multivariate regression models. To address the second correlation, age was excluded from the regression models.

Based upon their importance in the existing scientific literature on BTSCC and to reduce confounding among independent variables, control variables were retained for binary measures for whether a farm was located in MI, whether they had sand bedding (Hogan and Smith, 2012), whether a farm was in the largest 90th percentile of herd size (Norman et al., 2011), and whether they 
employed nonfamily employees (Fuhrmann, 2002). This resulted in a refined model with 10 independent variables (model 1).

When performing ordinary least squares regression for the subpopulation of respondents with nonfamily employees, the additional independent variables related to employee management were added in the model with nonfamily employees, again refined using backward stepwise regression. This resulted in a refined model with 15 independent variables (model 2).

\section{RESULTS}

\section{Survey Response Rate and Representative Sample}

Of the 1,700 dairy farms in the initial sample, 79 $(4.6 \%)$ had an incorrect address or were no longer a working farm. Thus, 1,621 valid farms were sampled, of which 660 farms (41\%) responded to our survey. The response rate among valid farms was $21 \%$ in $\mathrm{FL}(25$ of 119), $39 \%$ in MI (291 of 737), and $45 \%$ in PA (344 of 765). Of the 660 responding farms, 32 respondents did not complete at least $50 \%$ of the survey and were excluded from analysis. Thus, a total of 628 cases were used in analysis. A total of $41 \%$ of surveys were received after the first mailing, an additional 20\% after one reminder postcard, an additional $25 \%$ after the third mailing, an additional $11 \%$ after the fourth mailing, and an additional $5 \%$ after the fifth mailing.

Comparison with USDA-reported state averages confirmed that our sample was largely representative. Herd size of respondents ranged from 9 to 5,800 cows, with an average herd size of 107 cows $(\mathrm{SEM}=4.7)$ and median of 66 cows. Average daily production for our sample herds was $31.1,33.0$, and $32.3 \mathrm{~kg} /$ cow per day for FL, MI, and PA, respectively, compared with USDA-reported state averages of 31.1, 35.2, and 32.1 $\mathrm{kg} /$ cow per day for FL, MI, and PA, respectively. Only the MI respondents reported having a different production average $(P<0.0001)$ than the USDA-reported average (Norman et al., 2011). State average herd size in our sample was 1,085, 187, and 76 cows, which did not differ from USDA-reported state averages of 939, 177 , and 75 cows for FL, MI, and PA, respectively (lowest $P=0.43$; USDA Economic Research Service, 2014). The PA respondents reported an average BTSCC of approximately 202,000 cells $/ \mathrm{mL}$, which was lower $(P$ $<0.05)$ than the USDA-reported average of 212,000 cells/mL. Averages for our survey farms in FL (approximately 244,000 cells/mL) and MI (approximately 163,000 cells $/ \mathrm{mL}$ ) did not differ from USDA-reported averages, 229,000 and 165,000 cells/mL for FL and MI, respectively (lowest $P=0.57$; Norman et al., 2011).

\section{Sociodemographics of Sample}

Our sample of respondents was 90\% male, 99\% white, and $75 \%$ with English as their first language. Respondents had spent an average of $27 \mathrm{yr}$ working on their dairy farm. In terms of their position in the dairy farm, $53 \%$ were sole proprietors of their farm, $37 \%$ joint owners with family, and $6 \%$ managers on the farm. Forty-two percent had less than a high school education, $37 \%$ had a high school degree, whereas $12 \%$ had some college, and $9 \%$ had a college education.

\section{BTSCC}

Respondents reported a mean BTSCC of approximately 186,000 cells $/ \mathrm{mL}(\mathrm{SEM}=4,600)$ for the most recent month before the survey, 192,000 cells/mL (SEM $=4,500)$ for the previous month, and 197,000 cells $/ \mathrm{mL}$ $(\mathrm{SEM}=4,900)$ for $2 \mathrm{mo}$ prior. The overall 3 -mo geometric mean BTSCC among respondents was 194,000 cells $/ \mathrm{mL}(\mathrm{SEM}=4,000)$.

\section{Factor Analysis}

Principal components factor analysis with Varimax rotation confirmed the retention of 6 scales as composite independent variables (Table 1). The first 3 scales represent respondents' goal orientations: reducing antibiotics goals, milk quality goals, and long-term farm goals. Three variables were retained in the reducing antibiotics goals scale that loaded strongly on a single factor (Table 1). Two variables were retained in the milk quality goals scale that loaded strongly on a single factor (Table 1). Six variables were retained in the long term farm goals scale that loaded strongly on a single factor (Table 1).

The fourth scale represented respondents' attitudes regarding causes of mastitis: mastitis problems attitude. Three variables were retained in the mastitis problems attitude scale that loaded strongly on a single factor (Table 1). The fifth scale represented respondents' employee management priorities: engaged employee management. Eight variables were retained that loaded strongly on a single factor (Table 1). The final scale represented respondents' reported practices for culturing milk samples: culturing practices. Three variables were retained in the culturing practices scale that loaded strongly on a single factor (Table 1). These 6 scales were then evaluated as independent variables in both bivariate and multivariate analysis.

\section{Bivariate}

The descriptive statistics for selected independent variables tested in multiple regression are displayed 
in Table 2 (binary variables) and Table 3 (continuous and ordinal variables). Comparison of means (Table 4) indicated 18 binary independent variables that met the threshold for inclusion in the multivariate regression $(P$ $<0.10$ ). Bivariate correlations (Table 5) indicated 15 continuous or ordinal variables that met the threshold for inclusion in the multivariate regression $(P<0.10)$. Appendix Table A1 provides the bivariate correlations for all 55 continuous or ordinal independent variables tested. Appendix Table A2 provides the comparison of means for all 38 binary independent variables tested. Appendix Table A3 provides a full frequency distribution for each of the ordinal variables that met the $P<$ 0.10 threshold in bivariate analysis.

\section{Multivariate Regressions}

The final regression model for all respondents includes 6 independent variables that were associated with BTSCC (Table 6). Use of an internal teat sealant and the interaction between being from MI and having sand bedding were associated with lower BTSCC. Conversely, English as a native language, using a vaccine to control Staphylococcus aureus mastitis, the mastitis problems attitude scale (see Table 1 for components) and having a threshold of concern for BTSCC >300,000 cells $/ \mathrm{mL}$ were associated with higher BTSCC.

The final regression model that includes only the subpopulation of respondents with nonfamily employees included 9 independent variables that were associated with BTSCC (Table 6). Use of BDCT, ensuring strict compliance with milking protocols, the relative importance of reducing labor costs as a farm goal, and if employees received a financial or other penalty if SCC increases were associated with lower BTSCC. Conversely, a respondent reporting a higher number of years of experience on the dairy farm, being part of the 90th percentile of herd size (having $\geq 600$ cows), washing or spraying udders with water before milking, the mastitis problems attitude scale (see Table 1 for components), and again having a threshold of concern for BTSCC >300,000 cells $/ \mathrm{mL}$ were associated with higher BTSCC.

Table 1. Principal component factor analysis for independent variables from a survey of 628 dairy herds in Florida, Michigan, and Pennsylvania

\begin{tabular}{|c|c|c|c|}
\hline Item & Factor loading & Eigenvalue & Cronbach's $\alpha$ \\
\hline Reducing antibiotics goals & & 2.49 & 0.91 \\
\hline Reducing use of antibiotics for mastitis ${ }^{1}$ & 0.83 & & \\
\hline Reducing antibiotic residue in milk ${ }^{1}$ & 0.95 & & \\
\hline Reducing antibiotic residue in culled cows ${ }^{1}$ & 0.95 & & \\
\hline Milk quality goals & & 1.73 & 0.81 \\
\hline Improving milk quality $^{1}$ & 0.93 & & \\
\hline Receiving a financial incentive for milk quality ${ }^{1}$ & 0.93 & & \\
\hline Long-term farm goals & & 3.82 & 0.89 \\
\hline Staying in the dairy business ${ }^{1}$ & 0.77 & & \\
\hline Increasing income or profits ${ }^{1}$ & 0.85 & & \\
\hline Setting up the farm for the next generation ${ }^{1}$ & 0.61 & & \\
\hline Improving the image of dairy products ${ }^{1}$ & 0.79 & & \\
\hline Improving herd health ${ }^{1}$ & 0.87 & & \\
\hline Reducing feed costs ${ }^{1}$ & 0.85 & & \\
\hline Mastitis problems attitude & & 1.89 & 0.67 \\
\hline Mastitis is a problem on my farm ${ }^{2}$ & 0.65 & & \\
\hline Not following milking protocols is a problem on my farm ${ }^{2}$ & 0.87 & & \\
\hline Not following treatment protocols is a problem on my farm ${ }^{2}$ & 0.85 & & \\
\hline Engaged employee management ${ }^{3}$ & & 4.86 & 0.92 \\
\hline Recruiting good employees ${ }^{1}$ & 0.85 & & \\
\hline Retaining good employees ${ }^{1}$ & 0.84 & & \\
\hline Motivating employees with positive feedback ${ }^{1}$ & 0.87 & & \\
\hline Closely supervising employees ${ }^{1}$ & 0.65 & & \\
\hline Setting goals for employees ${ }^{1}$ & 0.76 & & \\
\hline Including employees in setting farm goals ${ }^{1}$ & 0.68 & & \\
\hline Evaluating employee performance ${ }^{1}$ & 0.76 & & \\
\hline Providing training opportunities for employees ${ }^{1}$ & 0.79 & & \\
\hline Culturing practices & & 1.93 & 0.74 \\
\hline Culture milk samples from high SCC or conductivity cows ${ }^{2}$ & 0.91 & & \\
\hline Culture milk samples from clinical mastitis cases ${ }^{2}$ & 0.89 & & \\
\hline Culture bulk tank milk samples ${ }^{2}$ & 0.55 & & \\
\hline
\end{tabular}

${ }^{1} 1=$ very unimportant, $2=$ unimportant, $3=$ neither, $4=$ important, $5=$ very important.

${ }^{2} 1=$ never, $2=$ sometimes, $3=$ frequently, $4=$ always.

${ }^{3}$ Only including the subpopulation of farms with nonfamily employees. 
Table 2. Descriptive statistics for binary independent variables used for multivariate models from a survey of 628 dairy herds in Florida, Michigan, and Pennsylvania by bulk tank somatic cell count (BTSCC) category

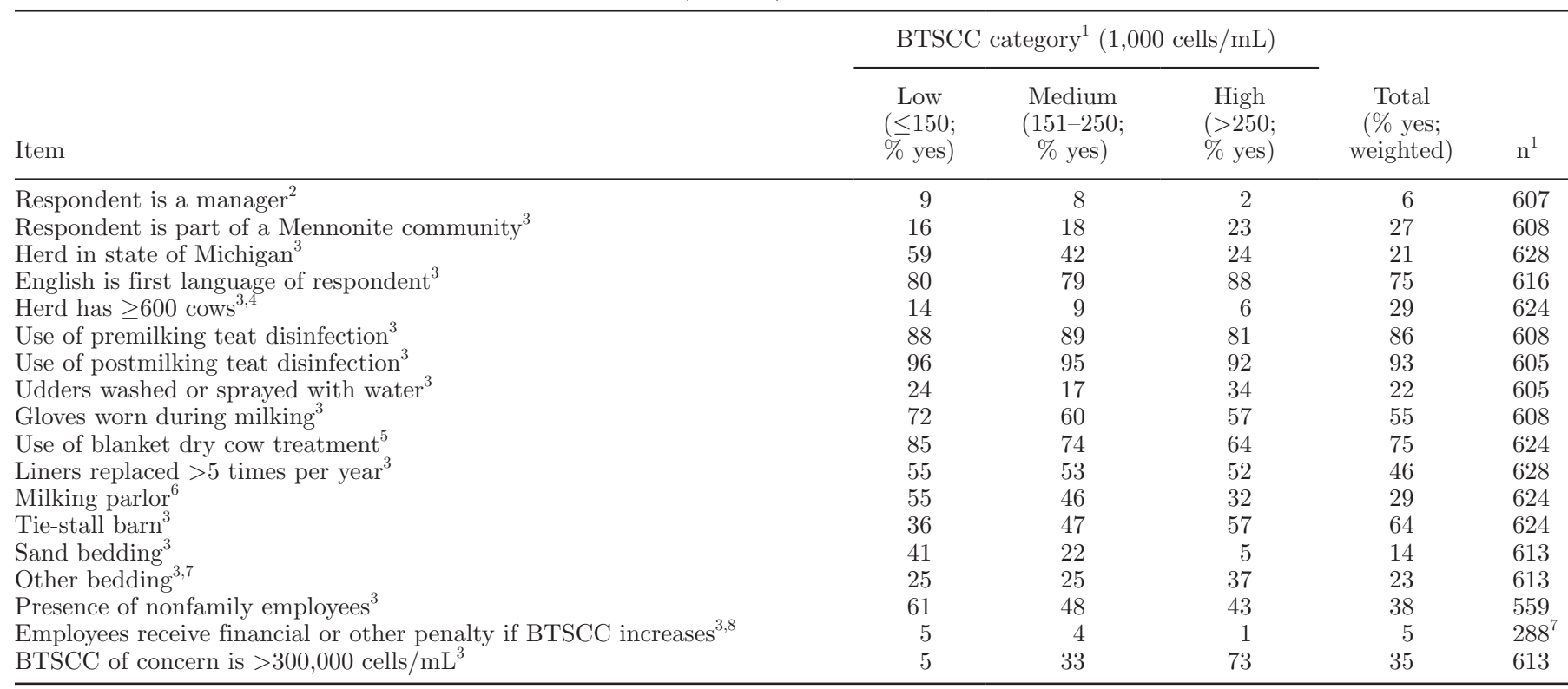

\footnotetext{
${ }^{1}$ Unweighted.

${ }^{2} 1=$ yes (manager) and $0=$ no (sole proprietor, joint owner with family, leasing, nonfamily partner, or other).

${ }^{3} 1=$ yes and $0=$ no.

${ }^{4}$ Farms with $\geq 600$ milking cows represent the 90th percentile of herd size.

${ }^{5} 0=$ never, sometimes, or frequently, $1=$ always.

${ }^{6}$ Including side in - side out parlors (weighted $\mathrm{n}=21$ ), herringbone parlors (weighted $\mathrm{n}=574$ ), parallel parlors $($ weighted $\mathrm{n}=220$ ), rotary parlors (weighted $n=3$ ), and swingline parlors (weighted $n=51$ ).

${ }^{7}$ Yes = not mattress; platform with straw, sawdust, or wood shavings; recycled manure; sand; straw, sawdust, or wood shavings with loose housing; or pasture.

${ }^{8}$ Only including the subpopulation with nonfamily employees.
}

\section{DISCUSSION}

The overall goal of our survey was to identify herd management and social variables that may have an effect on the prevalence of mastitis in dairy herds, as measured by BTSCC. Several well-established herd management practices and behaviors were related to BTSCC in this study, whereas several social variables such as employee management and attitudes were also related to BTSCC. To the best of our knowledge, this is also the first study to systematically examine the relationship between employee management and udder health in North America. Together, the findings highlight the need for a comprehensive approach to managing mastitis, one that includes the human dimensions of management to maintain the practice of scientifically validated mastitis control procedures.

Although considerable variation was still present in the adoption of mastitis control practices by dairy producers, bivariate analyses suggested that several behaviors and management practices that have long been recognized as important practices to improve milk quality and BTSCC, such as PMTD and BDCT (Erskine et al., 1987; Jayarao et al., 2004; Wenz et al., 2007), should be included in multivariate analyses. However, the majority of these variables were not retained in the final multivariate models. Some of these practices were highly adopted in our population of herds; for example, 93\% of herds responded that they practiced PMTD. Thus, this likely resulted in not enough variation within the data set to demonstrate statistical significance in multivariate analysis.

Nonetheless, the multivariate analyses included 3 well-established management practices. Both BDCT and use of an internal teat sealant were associated with lower BTSCC whereas use of water in milking preparation was associated with higher BTSCC. In the case of BDCT, this was despite the high rate of use $(75 \%)$, which was similar to that found by Olde Riekerink et al. (2010; 72\%) in a Canadian study. The negative association of BDCT, internal sealants, and not using water in milking preparation with herd SCC is well established (Erskine et al., 1987; Godden et al., 2003; Bhutto et al., 2011; Dufour et al., 2011; Mütze et al., 2012). Some investigators have suggested that the benefits of BDCT, as opposed to selective therapy, 
Table 3. Descriptive statistics (mean) for ordinal and continuous independent variables used for multivariate models from a survey of 628 dairy herds in Florida, Michigan, and Pennsylvania by bulk tank somatic cell count (BTSCC) category

\begin{tabular}{|c|c|c|c|c|c|c|c|c|c|}
\hline \multirow[b]{3}{*}{ Item } & \multicolumn{6}{|c|}{ BTSCC category $(\text { cells } / \mathrm{mL})^{1}$} & \multirow{3}{*}{$\begin{array}{c}\text { Overall } \\
\text { mean }\end{array}$} & \multirow[b]{3}{*}{$\mathrm{SEM}^{2}$} & \multirow[b]{3}{*}{$\mathrm{n}^{1}$} \\
\hline & \multicolumn{2}{|c|}{$\begin{array}{l}\text { Low } \\
(\leq 150)\end{array}$} & \multicolumn{2}{|c|}{$\begin{array}{c}\text { Medium } \\
(151-250)\end{array}$} & \multicolumn{2}{|c|}{$\begin{array}{l}\text { High } \\
(>250)\end{array}$} & & & \\
\hline & Mean & $\mathrm{SEM}^{2}$ & Mean & $\mathrm{SEM}^{2}$ & Mean & $\mathrm{SEM}^{2}$ & & & \\
\hline Age of respondent (yr) & 46 & 1.1 & 49 & 0.9 & 50 & 1.2 & 47.3 & 0.6 & 615 \\
\hline Number of years of respondent on the dairy farm & 25 & 1.2 & 29 & 1.1 & 32 & 1.6 & 27.1 & 1.0 & 614 \\
\hline How often is the entire milking system evaluated? ${ }^{3}$ & 2.0 & 0.1 & $\begin{array}{l}.00 \\
1.9\end{array}$ & 0.1 & 1.7 & 0.1 & $\begin{array}{l}0.0 \\
1.9\end{array}$ & 0.0 & 584 \\
\hline Use an internal teat sealant (at dry off $)^{3}$ & 2.6 & 0.1 & 2.3 & 0.1 & 2.2 & 0.1 & 2.3 & 0.1 & 591 \\
\hline Use vaccine to control Staphylococcus aureus mastitis ${ }^{3}$ & 1.4 & 0.1 & 1.5 & 0.1 & 1.6 & 0.1 & 1.4 & 0.0 & 575 \\
\hline Ensure strict compliance with milking protocols ${ }^{3,4}$ & 3.4 & 0.1 & 3.3 & 0.1 & 3.3 & 0.1 & 3.4 & 0.1 & $275^{4}$ \\
\hline Engaged employee management (scale) ${ }^{4,5,6}$ & 4.0 & 0.1 & 3.9 & 0.1 & 3.7 & 0.1 & 4.0 & 0.1 & $249^{4}$ \\
\hline Employees play an important role in mastitis problems ${ }^{4,7}$ & 4.1 & 0.1 & 3.8 & 0.1 & 3.7 & 0.1 & 4.1 & 0.1 & $282^{4}$ \\
\hline Reducing labor costs as farm goal ${ }^{4,7}$ & 3.9 & 0.1 & 3.6 & 0.1 & 3.6 & 0.1 & 3.9 & 0.1 & $284^{4}$ \\
\hline
\end{tabular}

${ }^{1}$ Unweighted.

${ }^{2}$ Taylor linearized.

${ }^{3} 1=$ never, 2 = sometimes, $3=$ frequently, $4=$ always.

${ }^{4}$ Only including the subpopulation with nonfamily employees.

${ }^{5}$ Average of responses to questions related to the importance of employee management strategies: recruiting good employees, retaining good employees, motivating employees with positive feedback, closely supervising employees, setting goals for employees, including employees in setting farm goals, evaluating employee performance, providing training opportunities for employees.

${ }^{6} 1=$ very unimportant, $2=$ unimportant, $3=$ neither, $4=$ important, $5=$ very important.

${ }^{7} 1=$ strongly disagree, $2=$ disagree, $3=$ neither, $4=$ agree, $5=$ strongly agree.

${ }^{8}$ Average of responses to questions related to attitudes concerning causes of mastitis: mastitis is a problem on my farm, not following milking protocols is a problem on my farm, not following treatment protocols is a problem on my farm.

may depend on the microbiological ecology of the herd and other management practices (Rajala-Schultz et al., 2011). Scherpenzeel et al. (2014) found that selective dry cow therapy, as opposed to BDCT, may result in a greater risk of clinical mastitis and higher SCC after calving.

Interestingly, the significance of these variables varied depending on the population of respondents. Use of water in milking preparation and BDCT were associated with BTSCC in the subpopulation of respondents with employees, and use of internal teat sealants was associated with lower BTSCC among all respondents. The reasons that $\mathrm{BDCT}$ is negatively associated and water use positively associated with BTSCC in farms with employees, as compared with the general population of respondents, is unclear. Likewise, the use of internal teat sealants was negatively associated with BTSCC among all respondents but not the subpopulation with employees. This suggests that differences may be present in confounding of variables between these subpopulations of herds due to variation in such factors as herd size, housing, bedding, and so on. For instance, a Swiss study found that management variables that are associated with the incidence of clinical mastitis and the proportion of high SCC cows within a herd may differ depending on the type of housing (freestall or tiestall) on a dairy farm (Gordon et al., 2013). The proportion of high SCC cows in tiestall systems was associated with $\mathrm{BDCT}$, clean bedding material at calving, and use of total merit values to select bulls (Gordon et al., 2013). The proportion of high SCC cows in freestall operations was not associated with any of these management variables (Gordon et al., 2013). Thus, the presence or lack of employees may in part be a proxy for other variables that will, as in the Swiss study, affect the association of BTSCC for variables in our study.

The multivariate regression model in this study showed no significant relationship between herd size and LnBTSCC in the general population once controlling for other variables in the model. This is similar to a report by Wenz et al. (2007) who also found that larger herds were not associated with lower BTSCC in their final logistic regression model. However, among respondents with employees, a positive relationship 
Table 4. Comparison of geometric mean bulk tank somatic cell count (BTSCC; $\times 1,000$ cells/mL) from a survey of 628 dairy herds in Florida, Michigan, and Pennsylvania by selected binary characteristics with $P<0.10$

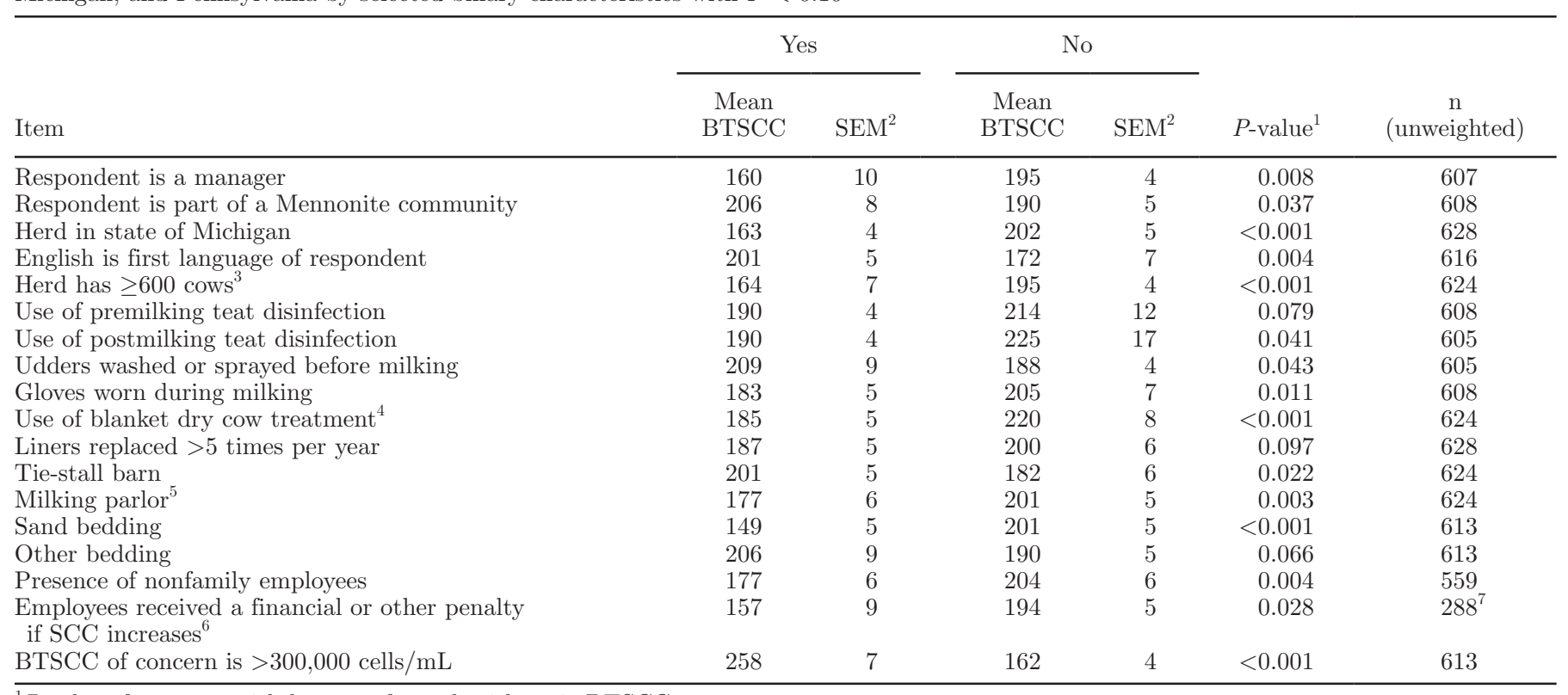

${ }^{1} P$-values for $t$-tests with log-transformed arithmetic BTSCC.

${ }^{2}$ Taylor linearized.

${ }^{3}$ Farms with $\geq 600$ milking cows represent the 90 th percentile of herd size.

${ }^{4} 0=$ never, sometimes, or frequently, $1=$ always.

${ }^{5}$ Including side in - side out parlors (weighted $\mathrm{n}=21$ ), herringbone parlors (weighted $\mathrm{n}=574$ ), parallel parlors (weighted $\mathrm{n}=220$ ), rotary parlors (weighted $n=3$ ), and swingline parlors (weighted $n=51$ ).

${ }^{6}$ Only including the subpopulation with nonfamily employees.

was found between herd size and BTSCC, specifically herds that represented the 90th percentile $(\geq 600$ cows or $8.6 \%$ of farms with nonfamily employees) of herd size. This is consistent with studies that have linked herd size to BTSCC (Norman et al., 2011; Archer et al., 2013). A study of herds in Ireland and the United Kingdom found that herd SCC increased as herd size increased (Archer et al., 2013), which the authors attributed to management challenges associated with expansion. A Canadian study found that an alternative measure of milk quality in bulk tank milk, coliform count, was also positively associated with larger herd size (Elmoslemany et al., 2010). However, other authors (Jayarao et al., 2004; Ingham et al., 2011) have found that larger herds were associated with lower BTSCC.

Our study suggests that one of the management challenges that may impede mastitis control in larger herds is employee management. Respondents that stated they ensure strict compliance of protocols and give employees a financial or other penalty if SCC increases were more likely to have lower BTSCC, as were those who place more importance on reducing labor costs as a farm goal. This is in agreement with other authors who suggested that adequate workforce management is the most common challenge to producers following expansion and is a predictor of overall success of the expansion (Fuhrmann, 2002). Increasingly, US dairy farms rely on nonfamily employees (Jackson-Smith and Barham, 2000; Cross, 2006), but training and human resource management have not kept up with these trends (Fuhrmann, 2002; Brasier et al., 2006; Stup et al., 2006). In addition to training, methods of employee engagement may be of value to help control mastitis. Together, our survey findings and previous reports suggest that human resource issues are a crucial domain that should be considered in mastitis management.

In addition to employee-related issues, the potential association of herd size with mastitis is further confounded by differences in housing and milking systems that vary by herd size. In a Swedish study, freestall herds with milking parlors implemented more preventive measures related to milking hygiene and milking routines than did tie-stall herds (Nielsen and Emanuelson, 2013). However, a milking order based on the udder health status of the cows was frequently implemented in tie-stall herds, but not in most herds with an automated milking system or most freestall herds with milking parlors (Nielsen and Emanuelson, 2013).

Ample evidence indicates that use of inorganic bedding such as sand is strongly associated with lower 
Table 5. Correlations with log-transformed arithmetic mean bulk tank somatic cell count (BTSCC) from a survey of 628 dairy herds in Florida, Michigan, and Pennsylvania by selected ordinal and continuous characteristics with $P<0.10$

\begin{tabular}{|c|c|c|c|}
\hline Item & $\begin{array}{c}\text { Pearson's } \\
\text { correlation } \\
\text { with BTSCC }\end{array}$ & $\begin{array}{c}P \text {-value } \\
(2 \text {-tailed })\end{array}$ & $\begin{array}{c}\mathrm{n} \\
\text { (unweighted) }\end{array}$ \\
\hline $\begin{array}{l}\text { Age of respondent } \\
\text { Number of years of respondent on the dairy farm } \\
\text { Singe hair on the udders }{ }^{1} \\
\text { Clean alleys/gutters after or during each milking }{ }^{1} \\
\text { How often is the entire milking system evaluated? } \\
\text { Use an internal treat sealant at dry off }^{2} \\
\text { Use vaccine to control Staphylococcus aureus mastitis }^{1} \\
\text { Ensure strict compliance with milking protocols } \\
\text { Engaged employee management }\left(\text { scale }^{3,4,5}\right. \\
\text { Employees play an important role in mastitis problems } \\
\text { Reducing labor costs as farm goal }{ }^{3,4} \\
\text { Mastitis problems attitude (scale })^{6,7} \\
\text { Weather plays an important role in mastitis problems } \\
\text { Bad luck plays an important role in mastitis problems } \\
\text { Milking equipment plays an important role in mastitis problems }\end{array}$ & $\begin{array}{r}0.14 \\
0.15 \\
-0.08 \\
-0.11 \\
-0.09 \\
-0.11 \\
0.12 \\
-0.07 \\
-0.13 \\
-0.16 \\
-0.08 \\
0.25 \\
0.09 \\
0.12 \\
-0.08\end{array}$ & $\begin{array}{r}<0.001 \\
<0.001 \\
0.048 \\
0.019 \\
0.028 \\
0.016 \\
0.008 \\
0.077 \\
0.029 \\
<0.001 \\
0.055 \\
<0.001 \\
0.036 \\
0.005 \\
0.051\end{array}$ & $\begin{array}{l}615 \\
614 \\
596 \\
597 \\
584 \\
591 \\
575 \\
275^{4} \\
249^{4} \\
282^{4} \\
284^{4} \\
585 \\
552 \\
597 \\
611\end{array}$ \\
\hline
\end{tabular}

BTSCC and incidence of clinical mastitis, especially that caused by environmental pathogens (Dufour et al., 2011; Hogan and Smith, 2012) and that sand results in better cow comfort and lower bacterial numbers in bedding (van Gastelen et al., 2011; Hogan and Smith, 2012). However, none of the housing or bedding variables was significantly related to BTSCC in the final multivariate models. As stated earlier with other mastitis control practices, the lack of significance in the multivariate analysis may be due in part to confounding with other mastitis practices and among housing and bedding (for instance, only 13 herds use both tie-stall housing and sand bedding). This was particularly the case in herds in MI, where a significant interaction between sand and being a herd from that state was found across the entire population of study herds. This may have played a role in the lower BTSCC among herds in Michigan relative to herds in PA and FL. However, in a Pennsylvania study of 126 dairy herds (Jayarao et al., 2004) larger herd size, but not use of sand bedding, was determined to be associated with lower BTSCC, and the largest herd size category in the study ( $>200$ cows) did not use sand more frequently than herds with fewer cows. We were unable account for other important housing and bedding variables such as maintenance of the stalls, size of the stalls relative to the animals being housed, social hierarchy interactions, ventilation, and stocking density; all of which may affect the hygiene and hence exposure to environmental mastitis pathogens. The sum of these reports confirm that despite the use of sand in freestalls, the effect of housing and bedding on the incidence of intramammary infections and BTSCC is multifactorial and difficult to fully explain with survey studies without knowledge of application of management practices among farms.

Several measures of attitudes and values were associated with BTSCC in this study, consistent with studies finding that attitudes of farm managers and owners about mastitis and milk quality may affect SCC, mastitis incidence, and use of antimicrobial agents (BigrasPoulin et al., 1985; Barkema et al., 1999; Vaarst et al., 2002; Barnouin et al., 2004; Sato et al., 2008). In our study, respondents that scored higher on the mastitis problems attitude scale-belief that mastitis was a problem on their farm and that not following milking and treatment protocols was a problem-reported higher BTSCC. This finding confirms results of Jansen et al. (2009) that farmers' attitudes and beliefs toward mastitis and their sense of whether or not they could control mastitis was significantly related to BTSCC. This effect was common across both multivariate models. Likewise, the threshold of concern of respondents 
Table 6. Final multivariate ordinary least squares regression analysis of log-transformed arithmetic mean bulk tank somatic cell count (BTSCC) on selected variables from a survey of 628 dairy herds in Florida, Michigan, and Pennsylvania ${ }^{1}$

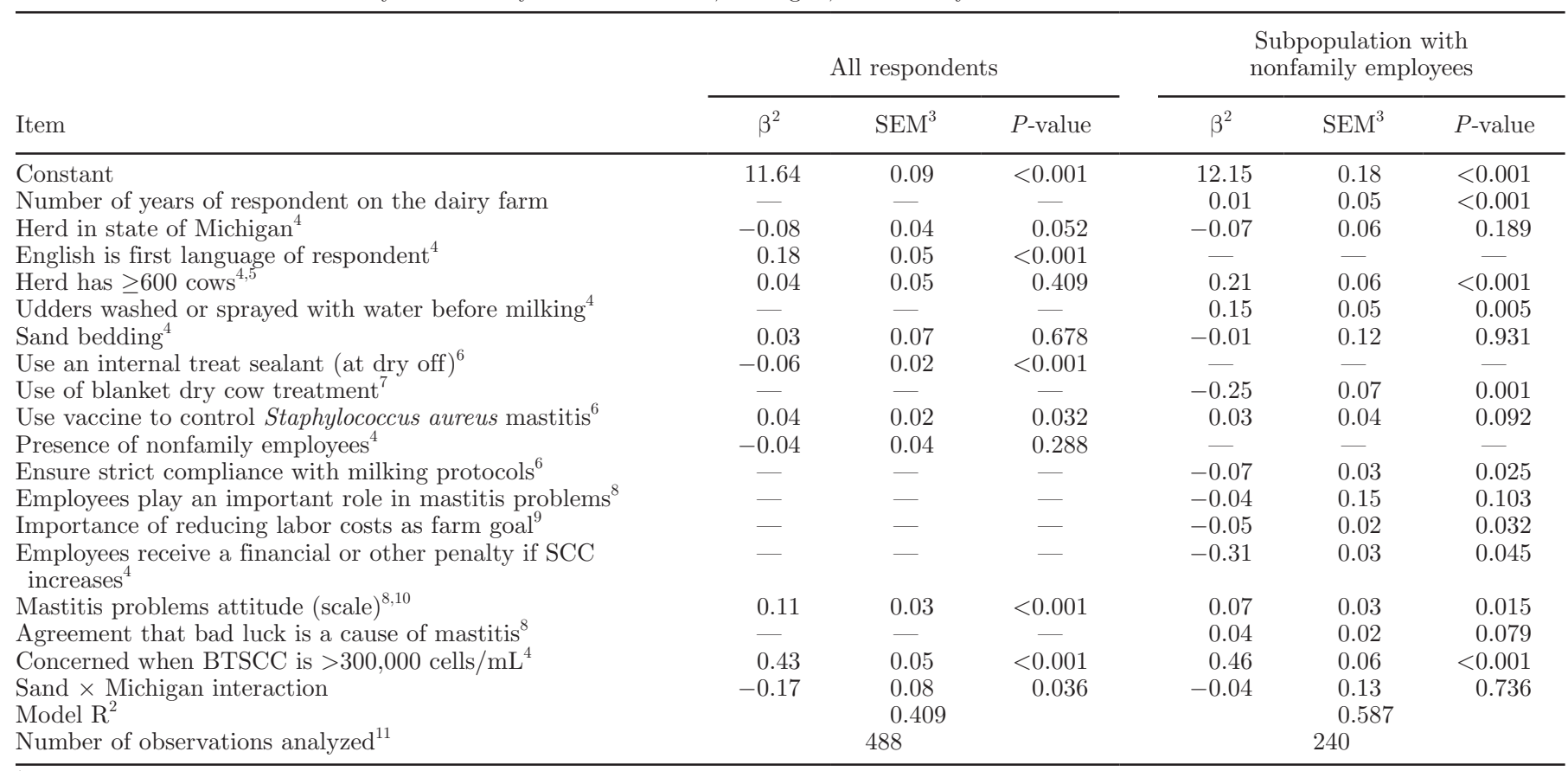

${ }^{1}$ Model 1 included all farms in the survey sample (excluding those with missing data); model 2 included farms that reported having nonfamily employees (excluding those with missing data).

${ }^{2}$ Standardized coefficient $(\beta)$.

${ }^{3}$ Taylor linearized.

${ }^{4} 1=$ yes and $0=$ no.

${ }^{5}$ Farms with $\geq 600$ milking cows represent the 90th percentile of herd size.

${ }^{6} 1=$ never, 2 = sometimes, $3=$ frequently, 4 = always.

${ }^{7} 0=$ never, sometimes, or frequently; $1=$ always.

${ }^{8} 1=$ strongly disagree, $2=$ disagree, $3=$ neither, $4=$ agree, $5=$ strongly agree.

${ }^{9} 1=$ very unimportant, $2=$ unimportant, $3=$ neither, $4=$ important, $5=$ very important.

${ }^{10}$ Average of responses to questions related to attitudes concerning causes of mastitis: mastitis is a problem on my farm, not following milking protocols is a problem on my farm, not following treatment protocols is a problem on my farm.

${ }^{11}$ Analysis excludes cases with missing data on one or more independent variables (list-wise deletion).

regarding BTSCC ("I get concerned when the BTSCC in my herd reaches...") was strongly associated with higher BTSCC, across both multivariate models. Similar to the findings of Barkema et al. (1999) showing that herd management style and attitudes, described as "clean and accurate" or "quick and dirty," affect the incidence of clinical mastitis and particularly BTSCC, herd managers in our study that stated they had difficulty in following protocols (within the attitude scale) were more likely to have higher BTSCC. These findings, coupled with attitudes toward employee management, confirmed our hypotheses that farmer attitudes, values, and beliefs are an integral part of mastitis control and highlight the need for a comprehensive approach to managing mastitis that incorporates human dimensions and attitudes.

The associations that can be inferred between BTSCC and survey variables that remained in the mul- tivariate model have limitations. Actual behaviors (e.g., full coverage of teats while using PMTD) cannot be verified and results rely only on reported behaviors by respondents. This study used a variety of methods to minimize potential response bias associated with mail surveys and self-reports, including ordering questions by topic, simplifying response categories and maintaining consistency, offering clear survey instructions, and pretesting the survey (Schaeffer and Presser, 2003; Dillman et al., 2009). Nonetheless, surveys administered by mail, especially those that ask respondents to describe attitudes and behaviors, have some drawbacks. Also, despite pretesting the survey, ambiguous interpretation of questions may arise, especially when mailed to a diverse population of 1,700 farms. However, in the interest of keeping the survey to a length that would promote completion, a balance between practicality and depth of data was reached. Despite potential limitations, the 
results in this study confirm and extend the findings of several existing studies on BTSCC.

Additionally, depending if a respondent was a herd owner or manager, attitudes regarding employees, or beliefs of how management practices are being done and actual compliance may differ. This might explain why some of the variables that were not significantly associated with BTSCC in our survey were reported to be beneficial in controlling mastitis in earlier studies. As previously stated, the BTSCC reported from farms in our study represented mostly winter months. Season has been found to be a significant predictor of bacterial counts in milk, with the lowest counts tending to be in winter (Elmoslemany et al., 2010). Thus, variables such as bedding, which are likely to have a larger effect on rates of environmental IMI in warmer weather (Hogan and Smith, 2012), may have had a stronger association if the reported BTSCC represented summer months.

The goal of this study was to examine the effect of management practices and social variables on mastitis control, across diverse farms. Michigan, PA, and FL have diverse dairy industry structures, including herd size, farmer characteristics, employment practices, and herd management, as well as diverse climates. We had a relatively high response rate across the entire sample, although the response rate was not as robust from FL and may have limited the analysis of herds representing this climate and management structure. Multivariate analysis allowed us to control for these differences through the inclusion of appropriate control variables, and helped us to isolate the effects of specific practices and attitudes from confounding relationships with farm structure and other variables. Differences between our bivariate and multivariate results suggest that further study is needed to help account for the multiple confounding relationships among region, structure, and practices to more clearly identify the management practices and social variables most strongly associated with BTSCC.

A weakness with our approach was the probable imbalanced representation of certain management practices and herd size among states, which impeded our ability to separate confounding variables. For example, all but 2 of the respondents in FL had employees, which is typical of large dairies. These herds are likely to have a more mature employee management structure than herds in MI and PA. Likewise, the high number of herds in Michigan that used sand bedding would indicate a tendency toward more modern freestall barn design (open sides, convective air flow, size of stalls, access to feed bunk space), as widespread adoption of sand and the housing and manure handling systems that are required to use this bedding material are rela- tively new technologies compared with tie stall barns in Pennsylvania.

Herd size is especially problematic for confounding of variables that may be associated with mastitis, not just from a perspective of physical variables (housing, milking facilities), but also variability in labor management. The dynamics between mangers and farm owners and employees is likely to be different in a herd with, for example, 200 cows and 2 to 3 employees that milk, than a herd with 4,000 cows and 15 to 20 employees assigned to diverse milking shifts. In many small to mediumsized herds, herd owners or managers may milk with employees during milking, whereas in larger herds, this is likely to be less common. The employee management culture (i.e., the relationship regarding communication and training) between farm management and employees can also vary between farms. For example, we found that an employee financial incentive linked to milk quality was associated with lower BTSCC. Thus, our study not only identified that the presence of employees may alter the mastitis management practices on a farm that are associated with BTSCC but also that the attitudes and practices of the management may be linked to mastitis control as well. The limitations of this study, designed to use responses from a survey administered remotely to farms, did not allow further exploration of in-depth employee management interactions and suggests the need for further study of milk quality and BTSCC in farms with nonfamily employees.

In summary, this study confirms the continued importance of several established management practices in addressing mastitis and BTSCC while also demonstrating the significance of several social variables. In particular, issues of employee management and training, as well as values and attitudes regarding mastitis were significantly related to BTSCC among respondents.

\section{ACKNOWLEDGMENTS}

This project was supported by Agriculture and Food Research Initiative Competitive Grant no. 2013-6800420439 from the USDA National Institute of Food and Agriculture.

\section{REFERENCES}

Archer, S. C., F. McCoy, W. Wapenaar, and M. J. Green. 2013. Association of season and herd size with somatic cell count for cows in Irish, English, and Welsh dairy herds. Vet. J. 196:515-521.

Barkema, H. W., J. D. Van Der Ploeg, Y. H. Schukken, T. J. G. M. Lam, G. Benedictus, and A. Brand. 1999. Management style and its association with bulk milk somatic cell count and incidence rate of clinical mastitis. J. Dairy Sci. 82:1655-1663.

Barnouin, J., M. Chassagne, S. Bazin, and D. Boichard. 2004. Management practices from questionnaire surveys in herds with very low 
somatic cell score through a national mastitis program in France. J. Dairy Sci. 87:3989-3999.

Bhutto, A. L., R. D. Murray, and Z. Woldehiwet. 2011. The effect of dry cow therapy and internal teat-sealant on intra-mammary infections during subsequent lactation. Res. Vet. Sci. 90:316-320.

Bigras-Poulin, M., A. H. Meek, S. W. Martin, and I. McMillan. 1985. Attitudes, management practices, and herd performance-A study of Ontario dairy farm managers. II. Associations. Prev. Vet. Med. $3: 241-250$.

Brasier, K., J. Hyde, R. E. Stup, and L. A. Holden. 2006. Farmlevel human resource management: An opportunity for extension. J. Ext. 44:rb3. Accessed May 19, 2015. http://www.joe.org/ joe/2006june/rb3.php.

Cha, E., J. A. Hertl, L. W. Tauer, G. Bennett, R. N. González, Y. H Schukken, F. L. Welcome, and Y. T. Gröhn. 2011. The cost and management of different types of clinical mastitis in dairy cows estimated by dynamic programming. J. Dairy Sci. 94:4476-4487.

Cross, J. 2006. Restructuring America's dairy farms. Geogr. Rev. 96:1-23.

Dillman, D. A., G. Phelps, R. Tortora, K. Swift, J. Kohrell, J. Berck, and B. L. Messer. 2009. Response rate and measurement differences in mixed-mode surveys using mail, telephone, interactive voice response (IVR) and the internet. Soc. Sci. Res. 38:1-18.

Dufour, S., A. Fréchette, H. W. Barkema, A. Mussell, and D. T. Scholl. 2011. Invited review: Effect of udder health management practices on herd somatic cell count. J. Dairy Sci. 94:563-579.

Elmoslemany, A. M., G. P. Keefe, I. R. Dohoo, J. J. Wichtel, H Stryhn, and R. T. Dingwell. 2010. The association between bulk tank milk analysis for raw milk quality and on-farm management practices. Prev. Vet. Med. 95:32-40.

Erskine, R. J., R. J. Eberhart, L. J. Hutchinson, and S. B. Spencer 1987. Herd management and prevalence of mastitis in dairy herds with high and low somatic cell counts. J. Am. Vet. Med. Assoc. 190:1411-1416.

Fuhrmann, T. J. 2002. Quality milk starts with quality management. Pages 131-139 in Natl. Mastitis Counc. Ann. Mtg. Proc., Orlando, FL, Natl. Mastitis Council, Inc., Verona, WI.

Godden, S., P. Rapnicki, S. Stewart, J. Fetrow, A. Johnson, R. Bey, and R. Farnsworth. 2003. Effectiveness of an internal teat sealant in the prevention of new intramammary infections during the dry and early-lactation periods in dairy cows when used with a dry cow intramammary antibiotic. J. Dairy Sci. 86:3899-3911.

Gordon, P., B. van den Borne, M. Reist, S. Kohler, and M. Doherr. 2013. Questionnaire-based study to assess the association between management practices and mastitis within tie-stall and freestall dairy housing systems in Switzerland. BMC Vet. Res. 9:200-210.

Hogan, J. S., and K. L. Smith. 2012. Managing environmental mastitis. Vet. Clin. North Am. Food Anim. Pract. 28:217-224.

Hogeveen, H., and T. J. Lam. 2011. Economic aspects of mastitis: New developments. N. Z. Vet. J. 59:16-23.

IBM Corp. 2012. IBM SPSS Statistics. Version 21.0. IBM Corp., Armonk, NY.

Ingham, S. C., Y. Hu, and C. Ané. 2011. Comparison of bulk-tank standard plate count and somatic cell count for Wisconsin dairy farms in three size categories. J. Dairy Sci. 94:4237-4241.

Jackson-Smith, D., and B. Barham. 2000. Dynamics of dairy industry restructuring in Wisconsin. Res. Rural Sociol. Dev. 8:115-139.

Jansen, J., B. H. P. van den Borne, R. J. Renes, G. van Schaik, T. J. G. M. Lam, and C. Leeuwis. 2009. Explaining mastitis incidence in Dutch dairy farming: The influence of farmers' attitudes and behaviour. Prev. Vet. Med. 92:210-223.

Jayarao, B. M., S. R. Pillai, A. A. Sawant, D. R. Wolfgang, and N. V. Hegde. 2004. Guidelines for monitoring bulk tank milk somatic cell and bacterial counts. J. Dairy Sci. 87:3561-3573.

Kenny, D. A. 1987. The two group design. Pages 203-223 in Statistics for the Social and Behavioral Sciences. Little, Brown, Boston, MA.
Kim, J., and C. W. Mueller. 1978. Factor analysis: statistical methods and practical issues. Series: Quantitative Applications in the Social Sciences. SAGE, Newbury Park, CA.

Losinger, W. 2005. Economic impacts of reduced milk production associated with an increase in bulk-tank somatic cell count on US dairies. J. Am. Vet. Med. Assoc. 226:1652-1658.

Ma, Y., C. Ryan, D. M. Barbano, D. M. Galton, M. A. Rudan, and K. J. Boor. 2000. Effects of somatic cell count on quality and shelf-life of pasteurized fluid milk. J. Dairy Sci. 83:264-274.

MacDonald, J., and D. Newton. 2014. Milk production continues shifting to large farms. US Department of Agriculture, Economic Report Service, Amber Waves, Dec. 1, 2014. Accessed May 19, 2015. http://www.ers.usda.gov/amber-waves/2014-december/ milk-production-continues-shifting-to-large-scale-farms.aspx\#. VJc6Ff8KQA.

McDowell, A., and J. Pitblado. 2002. From the Help Desk: It's all about the sampling. Stata J. 2:190-201.

Mein, G. A. 2012. The role of the milking machine in mastitis control Vet. Clin. North Am. Food Anim. Pract. 28:307-320.

Mütze, K. W. Wolter, K. Failing, B. Kloppert, H. Bernhardt, and M. Zschöck. 2012. The effect of dry cow antibiotic with and without an internal teat sealant on udder health during the first $100 \mathrm{~d}$ of lactation: A field study with matched pairs. J. Dairy Res. 79:477484.

Nielsen, C., and U. Emanuelson. 2013. Mastitis control in Swedish dairy herds. J. Dairy Sci. 96:6883-6893.

Norman, H. D., T. A. Cooper, and F. A. Ross Jr.. 2011. Somatic cell counts of milk from dairy herd improvement herds during 2010. A. I. P. L. Res. Reports SCC12:2-11.

Olde Riekerink, R. G. M., H. W. Barkema, D. T. Scholl, D. E. Poole, and D. F. Kelton. 2010. Management practices associated with the bulk-milk prevalence of Staphylococcus aureus in Canadian dairy farms. Prev. Vet. Med. 97:20-28.

Rajala-Schultz, P. J., A. H. Torres, and F. J. Degraves. 2011. Milk yield and somatic cell count during the following lactation after selective treatment of cows at dry-off. J. Dairy Res. 78:489-499.

Sato, K., P. C. Bartlett, L. Alban, J. F. Agger, and H. Houe. 2008. Managerial and environmental determinants of clinical mastitis in Danish dairy herds. Acta Vet. Scand. 50:4-12.

Schaeffer, N. C., and S. Presser. 2003. The science of asking questions, Annu. Rev. Sociol. 29:65-88.

Scherpenzeel, C. G., I. E. den Uijl, G. van Schaik, R. G. Olde Riekerink, J. M. Keurentjes, and T. J. Lam. 2014. Evaluation of the use of dry cow antibiotics in low somatic cell count cows. J. Dairy Sci. 97:3606-3614.

StataCorp. 2013. Stata Statistical Software. Release 13. StataCorp LP, College Station, TX.

Stup, R. E., J. Hyde, and L. A. Holden. 2006. Relationships between selected human resource management practices and dairy farm performance. J. Dairy Sci. 89:1116-1120.

USDA Economic Research Service. 2014. Milk cows and production by state and region (annual). Accessed May 19, 2015. http://www.ers. usda.gov/data-products/dairy-data.aspx\#.U-lNnoBdXUc.

Vaarst, M., B. Paarup-Laursen, H. Houe, C. Fossing, and H. J. Andersen. 2002. Farmers' choice of medical treatment of mastitis in Danish dairy herds based on qualitative research interviews. J. Dairy Sci. 85:992-1001.

van Gastelen, S., B. Westerlaan, D. J. Houwers, and F. J. C. M. van Eerdenburg. 2011. A study on cow comfort and risk for lameness and mastitis in relation to different types of bedding materials. J. Dairy Sci. 94:4878-4888.

Wenz, J. R., S. M. Jensen, J. E. Lombard, B. A. Wagner, and R. P. Dinsmore. 2007. Herd management practices and their association with bulk tank somatic cell count on United States dairy operations. J. Dairy Sci. 90:3652-3659. 


\section{APPENDIX}

Table A1. Correlations with log-transformed arithmetic mean bulk tank SCC from a survey of 628 dairy herds in Florida, Michigan, and Pennsylvania

\begin{tabular}{|c|c|c|}
\hline Item & $\begin{array}{c}\text { Pearson } \\
\text { correlation }\end{array}$ & $\begin{array}{c}\text { Significance } \\
\text { (2-tailed) }\end{array}$ \\
\hline Age & 0.135 & 0.001 \\
\hline Number of years on the dairy farm & 0.146 & $<0.001$ \\
\hline Singe hair on the udders & -0.084 & 0.044 \\
\hline Dock tails & -0.040 & 0.340 \\
\hline Educational attainment & -0.044 & 0.291 \\
\hline Mastitis problems attitude (scale) & 0.252 & $<0.001$ \\
\hline Bad luck plays an important role in mastitis problems & 0.119 & 0.004 \\
\hline Weather plays an important role in mastitis problems & 0.086 & 0.037 \\
\hline Milking equipment plays an important role in mastitis problems & -0.080 & 0.053 \\
\hline Stray voltage plays an important role in mastitis problems & 0.027 & 0.525 \\
\hline Concerned of percentage of mastitis cows reaches ( $\%$ of cows) & 0.222 & $<0.001$ \\
\hline Reduce antibiotic goal (scale) & -0.020 & 0.636 \\
\hline Milk quality goal (scale) & -0.059 & 0.159 \\
\hline Long-term farm goals (scale) & -0.045 & 0.288 \\
\hline Increasing herd size & -0.029 & 0.488 \\
\hline Increasing milk production & 0.031 & 0.452 \\
\hline Increasing off-farm income & 0.031 & 0.456 \\
\hline Preparing for retirement & 0.047 & 0.261 \\
\hline Reducing labor costs & -0.081 & 0.055 \\
\hline Sources of information: drug company representatives & -0.010 & 0.828 \\
\hline Sources of information: veterinarian & 0.000 & 0.992 \\
\hline Sources of information: milk cooperative & -0.017 & 0.702 \\
\hline Sources of information: cooperative extension & 0.026 & 0.527 \\
\hline Sources of information: farm journals & 0.023 & 0.600 \\
\hline Sources of information: other dairy producers & -0.016 & 0.710 \\
\hline Sources of information: Internet & -0.039 & 0.388 \\
\hline Clean alleys or gutters after or during each milking & -0.096 & 0.022 \\
\hline How much time elapses from when teats are first massaged (or stripped) until unit is attached? & 0.013 & 0.765 \\
\hline Ensure strict compliance with milking protocols & -0.074 & 0.083 \\
\hline How often are pulsators evaluated (graphed) for performance? & -0.032 & 0.445 \\
\hline How often is the entire milking system evaluated? & -0.093 & 0.027 \\
\hline Culturing practices (scale) & 0.003 & 0.940 \\
\hline Keep written or computer treatment records for all cows & 0.000 & 0.993 \\
\hline Milk mastitis and treated cows in a separate group & 0.019 & 0.666 \\
\hline Use an internal treat sealant (at dry off) & -0.101 & 0.016 \\
\hline Use anti-inflammatory drugs to treat clinical mastitis & 0.056 & 0.190 \\
\hline Use conductivity in milk to identify infected cows & -0.048 & 0.278 \\
\hline Use individual cow CSS to identify infected cows & 0.004 & 0.921 \\
\hline Use intramammary antibiotics to treat clinical mastitis & -0.036 & 0.389 \\
\hline Use oxytocin for milk let down & -0.054 & 0.195 \\
\hline Use vaccine to control Staphylococcus aureus mastitis & 0.118 & 0.006 \\
\hline Use vaccines to control coliform mastitis & -0.014 & 0.731 \\
\hline Treat mastitis cows for the full course of antibiotic doses & -0.068 & 0.106 \\
\hline Review treatment records before making treatment decisions & 0.023 & 0.582 \\
\hline Use systemic antibiotics to treat clinical mastitis & 0.031 & 0.474 \\
\hline Use oxytocin to treat clinical mastitis & 0.006 & 0.888 \\
\hline Use natural (organic) therapies to treat clinical mastitis & 0.058 & 0.182 \\
\hline Use alcohol pads before intramammary tube infusions & -0.037 & 0.375 \\
\hline Engaged management (scale) & -0.128 & 0.025 \\
\hline How often are you in the parlor and observing milking? & 0.023 & 0.597 \\
\hline Train employees in mastitis protocols & -0.048 & 0.310 \\
\hline Train employees in treatment protocols & 0.001 & 0.981 \\
\hline How often do you hold team meetings with milkers and other employees or professionals? & 0.000 & 0.997 \\
\hline Employees play an important role in mastitis problems & -0.161 & $<0.001$ \\
\hline
\end{tabular}


Table A2. Comparison of geometric mean bulk tank SCC $(\times 1,000$ cells $/ \mathrm{mL})$ from a survey of 628 dairy herds in Florida, Michigan, and Pennsylvania

\begin{tabular}{|c|c|c|c|c|c|}
\hline \multirow[b]{2}{*}{ Item } & \multicolumn{2}{|c|}{ Yes } & \multicolumn{2}{|c|}{ No } & \multirow[b]{2}{*}{$P$-value } \\
\hline & Mean & $\mathrm{SEM}^{2}$ & Mean & $\mathrm{SEM}^{2}$ & \\
\hline Respondent is male & 194 & 4 & 177 & 12 & 0.169 \\
\hline Respondent is white & 193 & 4 & 207 & 18 & 0.235 \\
\hline Percent of total household income from dairy $\geq 80 \%$ & 191 & 5 & 204 & 9 & 0.277 \\
\hline Respondent is sole proprietor & 191 & 6 & 191 & 6 & 0.738 \\
\hline Respondent is joint owner with family & 188 & 5 & 196 & 6 & 0.616 \\
\hline Respondent is leasing & 159 & 3 & 192 & 4 & 0.205 \\
\hline Respondent is nonfamily partner & 179 & 22 & 191 & 4 & 0.838 \\
\hline Respondent is manager & 160 & 10 & 195 & 4 & 0.008 \\
\hline Respondent is member of an Amish community & 178 & 8 & 197 & 5 & 0.128 \\
\hline Respondent is member of a Mennonite community & 206 & 8 & 190 & 5 & 0.037 \\
\hline Herd in state of Michigan & 163 & 4 & 202 & 5 & $<0.0001$ \\
\hline Herd in state of Pennsylvania & 201 & 5 & 165 & 4 & $<0.0001$ \\
\hline Herd has $\geq 600$ cows & 164 & 7 & 195 & 4 & 0.004 \\
\hline English is first language of respondent & 201 & 5 & 172 & 7 & 0.004 \\
\hline BTSCC of concern is $>300,000$ cells $/ \mathrm{mL}$ & 258 & 7 & 162 & 4 & $<0.0001$ \\
\hline Cows are milked after the automatic takeoff removes the unit & 191 & 8 & 187 & 7 & 0.391 \\
\hline Use of blanket dry cow treatment $^{3}$ & 185 & 5 & 220 & 8 & 0.0002 \\
\hline Teats are stripped before milking & 189 & 5 & 196 & 7 & 0.398 \\
\hline Teats are massaged before milking (other than stripping) & 189 & 7 & 192 & 5 & 0.446 \\
\hline Teats are dried before milking & 190 & 4 & 204 & 15 & 0.476 \\
\hline Use separate towels for each cow & 191 & 4 & 190 & 12 & 0.870 \\
\hline Gloves worn during milking & 183 & 5 & 205 & 7 & 0.011 \\
\hline Teats are disinfected before milking & 190 & 4 & 214 & 12 & 0.079 \\
\hline Teats are disinfected after milking & 190 & 4 & 225 & 17 & 0.041 \\
\hline Udders are washed or sprayed before milking & 209 & 9 & 188 & 4 & 0.043 \\
\hline Freestall barn & 189 & 5 & 199 & 7 & 0.301 \\
\hline Tie-stall barn & 201 & 5 & 182 & 6 & 0.022 \\
\hline Platform bedding & 177 & 18 & 189 & 5 & 0.949 \\
\hline Sand & 149 & 5 & 201 & 5 & $<0.0001$ \\
\hline Mattress $^{4}$ & 188 & 6 & 197 & 5 & 0.284 \\
\hline Other bedding ${ }^{5}$ & 206 & 9 & 190 & 5 & 0.066 \\
\hline Milking parlor ${ }^{6}$ & 186 & 6 & 197 & 6 & 0.234 \\
\hline Liners replaced $>5$ times per year & 187 & 5 & 200 & 6 & 0.097 \\
\hline Mastitis plan designed with or by veterinarian & 192 & 7 & 193 & 5 & 0.996 \\
\hline Presence of nonfamily employees & 177 & 6 & 204 & 6 & 0.004 \\
\hline Employees receive a financial or other incentive based on milk quality & 176 & 9 & 194 & 5 & 0.463 \\
\hline Employees received a financial or other penalty if SCC increases & 157 & 9 & 194 & 5 & 0.022 \\
\hline Cultural or language barriers in communicating with employees & 170 & 10 & 191 & 6 & 0.463 \\
\hline
\end{tabular}

${ }^{1} P$-values for $t$-tests with log-transformed arithmetic mean.

${ }^{2}$ Taylor linearized.

${ }^{3} 0=$ never, sometimes, or frequently, 1 = always.

${ }^{4}$ Yes $=$ mattress; platform with straw, sawdust, or wood shavings.

${ }^{5}$ Yes = not mattress; platform with straw, sawdust, or wood shavings; recycled manure; sand; straw, sawdust, or wood shavings with loose housing; or pasture.

${ }^{6}$ Including side in-side out parlors (weighted $\mathrm{n}=21$ ), herringbone parlors (weighted $\mathrm{n}=574$ ), parallel parlors (weighted $\mathrm{n}=220$ ), rotary parlors (weighted $n=3$ ), and swingline parlors (weighted $n=51$ ). 
Table A3. Frequency distribution of ordinal variables from a survey of 628 dairy herds in Florida, Michigan, and Pennsylvania

\begin{tabular}{|c|c|c|c|c|}
\hline Item & $\begin{array}{c}\text { Total } \\
\text { herds } \\
(\mathrm{n})\end{array}$ & Categories & $\begin{array}{l}\text { Weighted } \\
n\end{array}$ & $\underset{\%}{\text { Weighted }}$ \\
\hline \multirow[t]{3}{*}{ Frequency of singeing hair on the udders } & \multirow[t]{3}{*}{596} & Never & 1,879 & 65 \\
\hline & & Frequently & 201 & 7 \\
\hline & & Always & 239 & 8 \\
\hline Frequency of cleaning alleys or gutters after or during each milking & 597 & Never & 83 & 3 \\
\hline \multirow[t]{4}{*}{ How often is the entire milking system evaluated? } & \multirow[t]{4}{*}{584} & Less than once a year & 828 & 29 \\
\hline & & About once a year & 1,489 & 53 \\
\hline & & At least twice a year & 466 & 16 \\
\hline & & At least once a month & 48 & 2 \\
\hline \multirow[t]{2}{*}{ Frequency of keeping written or computer treatment records for all cows } & \multirow[t]{2}{*}{581} & Never & 1,042 & 37 \\
\hline & & Sometimes & 453 & 16 \\
\hline Frequency of using an internal treat sealant (at dry off) & 591 & Always & 1,127 & 39 \\
\hline \multirow[t]{4}{*}{ Frequency of using intramammary antibiotics at dry off (dry treatment) } & \multirow[t]{4}{*}{610} & Never & 292 & 10 \\
\hline & & Sometimes & 321 & 11 \\
\hline & & Frequently & 135 & 5 \\
\hline & & Always & 2,223 & 75 \\
\hline \multirow{4}{*}{ Use oxytocin for milk let down } & \multirow{4}{*}{549} & Never & 1,019 & 39 \\
\hline & & Sometimes & 439 & 17 \\
\hline & & Frequently & 132 & 5 \\
\hline & & Always & 1,025 & 39 \\
\hline Use vaccine to control Staphylococcus aureus mastitis & 575 & Never & 2,188 & 77 \\
\hline & & Sometimes & 336 & 12 \\
\hline & & Frequently & 62 & 2 \\
\hline & & Always & 239 & 8 \\
\hline Treat mastitis cows for the full course of antibiotic doses & 595 & Never & 281 & 10 \\
\hline & & Neither & 133 & 14 \\
\hline & & Agree & 464 & 48 \\
\hline & & Strongly agree & 318 & 33 \\
\hline Cooperative extension important source of information & 627 & Very unimportant & 367 & 12 \\
\hline & & Unimportant & 465 & 15 \\
\hline & & Neither & 1,448 & 47 \\
\hline & & Important & 704 & 23 \\
\hline & & Very important & 70 & 2 \\
\hline Milking equipment plays an important role in mastitis problems & 611 & Strongly disagree & 57 & 2 \\
\hline & & Disagree & 170 & 6 \\
\hline & & Neither & 206 & 7 \\
\hline & & Agree & 1,679 & 57 \\
\hline & & Strongly agree & 845 & 29 \\
\hline Bad luck plays an important role in mastitis problems & 597 & Strongly disagree & 814 & 28 \\
\hline & & Disagree & 956 & 33 \\
\hline & & Neither & 682 & 24 \\
\hline & & Agree & 329 & 12 \\
\hline & & Strongly agree & 81 & 3 \\
\hline Reducing labor costs as farm goal & 584 & Very unimportant & 25 & 3 \\
\hline & & Unimportant & 5 & 5 \\
\hline & & Neither & 188 & 19 \\
\hline & & Important & 440 & 45 \\
\hline & & Very important & 282 & 29 \\
\hline
\end{tabular}

